\title{
The Host Range of Downy Mildew, Peronospora parasitica, from Brassica oleracea, Cabbage and Broccoli Crops
}

\author{
Mamoru SATou* and Fumiyoshi FuKumoto*
}

\begin{abstract}
We collected three cabbage plants infected with Peronospora parasitica in Kagawa, two broccoli plants in Mie and one broccoli plant in Tottori. Five single spore isolates from each sample were prepared, and the host range of thirty single spore isolates in total was examined. Test plants used for the host range tests were Brassica oleracea (eighteen cultivars of cauliflower, cabbage and broccoli), $B$. campestris (eight cultivars of Pak-choi, mizuna, rape, Chinese cabbage and turnip), B. juncea (one cultivar of leaf mustard), B. napus (one cultivar of rutabaga) and Raphanus sativus (two cultivars of Japanese radish). In all the test plants, cotyledons with hypocotyl were used for the inoculation tests. All the $B$. oleracea plants except two cultivars of cabbage were highly susceptible to all the tested isolates, and it is considered that this is a host species of the fungus. $B$. napus was moderately susceptible, and suggested to be a possible host species. $B$. campestris, B. juncea and $R$. sativus were resistant, and considered to be non-host species. Therefore, all the isolates were considered to belong to the same strain of the fungus and the strain to be specific to $B$. oleracea and possibly to B. napus. Among B. oleracea plants, two cultivars of cabbage cv. Golden Best and cv. YR-Sawamidori were resistant. Difference in pathogenicity was not found among the tested single spore isolates.
\end{abstract}

(Received October 27, 1995; Accepted April 20, 1996)

Key words : Peronospora parasitica, downy mildew, Brassica oleracea, parasitism.

\section{INTRODUCTION}

Downy mildew fungus (Peronospora parasitica) of Cruciferae plants is well-known to comprise many strains with different host species specificities ${ }^{1-7,11,12)}$. Although the strains are principally species specific, they often show various degrees of pathogenicity to plants of other species, and the host ranges of the strains often overlaps each other. Therefore, to investigate certain problems of the disease, such as the epidemiology of the fungus on some crops and their cultivar resistance, first of all, it is necessary to know the host range of the tested isolates.

Only few information is available of the strains of the fungus distributing in Japan. Long before in 1934, Hiura and Kanegae ${ }^{5)}$ reported a particular investigation, in which they used downy mildew derived from Japanese radish (Raphanus sativus) and some Brassica plants, and the isolates were not pathogenic to cabbage $(B$. oleracea). In Japan, few report was found on host range of downy mildew on $B$. oleracea plants. Recently, we have observed the occurrence of downy mildew of broccoli and reported the host range of the fungus ${ }^{11}$. In this report, we showed the identity of the host range of the downy mildew fungus of cabbage and broccoli, and found resistant cultivars among $B$. oleracea plants using single spore isolates of the fungus.

\section{MATERIALS AND METHODS}

Fungal isolates. Three cabbage plants in Kagawa, two broccoli plants in Mie and one broccoli plant in Tottori which were infected with Peronospora parasitica were collected for the inoculation tests (Table 1). The downy mildew samples were brought to the laboratory in a cool box. One lesion was cut out and shaken in distilled water to prepare a conidial suspension. The suspension was spread on a plate of $1.5 \%$ water agar and one agar piece with a single conidium was cut off under a light microscope. The agar piece was transplanted onto the undersurface of a broccoli cotyledon (cv. Banrei) prepared on moist filter papers in petri dishes and incubated for seven days at $20^{\circ} \mathrm{C}$ in a growth cabinet (5000 lux, $12 \mathrm{hr}$ light/12 hr dark). Thirty agar pieces per one downy mildew sample were transplanted. The proportions of successful inoculation varied depending on the samples and ranged from $16.7 \%(5 / 30)$ to $60 \%(18 /$ 30). Five single spore isolates per each diseased sample were arbitrarily selected from the diseased cotyledons (Table 1). The isolates were maintained by periodical inoculation on broccoli cotyledons or preserved at $-80^{\circ} \mathrm{C}$

\footnotetext{
* National Research Institute of Vegetables, Ornamental Plants and Tea, 360 Kusawa, Ano-cho, Age-gun, Mie 514-23, Japan 野菜・茶業試験場
} 
Table 1. Single spore isolates of Peronospora parasitica used for the inoculation tests and their origin

\begin{tabular}{ccccc}
\hline \hline Single spore & \multicolumn{4}{c}{ Downy mildew samples for single spore isolation } \\
\cline { 2 - 5 } isolates & Crop & Sample No. & Location & Date of collection \\
\hline CPP5a,b,c,d,e & Cabbage & CPP5 & Kotonami, Kagawa & Nov. 1992 \\
CPP6a,b,c,d,e & Cabbage & CPP6 & Kotonami, Kagawa & Nov. 1992 \\
CPP7a,b,c,d,e & Cabbage & CPP7 & Kotonami, Kagawa & Nov. 1992 \\
BPP1a,b,c,d,e & Broccoli & BPP1 & Ano, Mie & Jan. 1990 \\
BPP2a,b,c,d,e & Broccoli & BPP2 & Daiei, Tottori & Nov. 1992 \\
BPP3a,b,c,d,e & Broccoli & BPP3 & Ureshino, Mie & Nov. 1992 \\
\hline
\end{tabular}

in a deep freezer ${ }^{10)}$ until use for the inoculation tests to avoid contamination with other downy mildew fungus.

Test plants. The Cruciferae plants used for the host range tests were Brassica oleracea (eighteen cultivars of cauliflower, cabbage and broccoli), B. napus (one cultivar of rutabaga), $B$. campestris (eight cultivars of Pak-choi, mizuna, rape, Chinese cabbage and turnip), B. juncea (one cultivar of leaf mustard) and Raphanus sativus (two cultivars of Japanese radish) as shown in Table 2 and 3. These test plants were sown in vermiculite in $7.5 \mathrm{~cm}$ plastic pots and grown for seven days in the growth cabinet to prepare seedlings at the stage of cotyledons for the inoculation tests under the condition described above.

Inoculation conditions. The seedlings of the test plants were cut at the hypocotyl, and the cotyledons, still remaining of hypocotyl, were placed in plastic cases (usually ten seedlings per each). The hypocotyls were winded with a piece of cotton wetted with distilled water or modified Knop's solution ${ }^{9)}$ to keep the freshness of the cotyledons. In some tests, to simplify the managements, cotyledons were transplanted in $1.5 \%$ water agar settled in plastic cases. Inoculum was prepared from the broccoli cotyledons with sporulation. Conidia were washed into distilled water and the concentration was adjusted to $1-5 \times 10^{4}$ conidia/ml with a Thoma hemacytometer. Five $\mu 1$ of the conidial suspension was placed on each cotyledon. Inoculated cotyledons were incubated for seven days under the conditions described above in a growth cabinet to develop disease lesions. Inoculation tests were replicated two to three times.

Disease assessment. The disease lesions of the inoculated cotyledons were observed macroscopically, and the disease indexes was calculated as the average of the percentage of diseased cotyledons as follows; 4 : sporulation on more than $50 \%$ of inoculated cotyledons, $3: 20 \%$ to $49 \%, 2$ : less than $19 \%, 1:$ sparse sporulation or large necrosis, $0:$ no sporulation or limited necrosis.

Table 2. Host reactions to single spore isolates of Peronospora parasitica on cotyledons in a differential host range set containing the four major cultivated species of Brassica and the synthetic genus Raphanus

\begin{tabular}{|c|c|c|c|c|c|c|c|c|c|}
\hline \multirow{2}{*}{\multicolumn{3}{|c|}{ Plants inoculated }} & \multicolumn{7}{|c|}{ Fungal isolates } \\
\hline & & & \multicolumn{4}{|c|}{ Cabbage } & \multicolumn{3}{|c|}{ Broccoli } \\
\hline \multirow{2}{*}{ Scientific name } & \multirow{2}{*}{ Crop } & \multirow{2}{*}{ Cultivar } & & CPP5 & CPP6 & $\mathrm{CPP} 7$ & BPP1 & BPP2 & BPP3 \\
\hline & & & $\mathrm{a}$ & bcde & abcde & abcde & $\overline{\text { abcde }}$ & $\overline{\text { abcde }}$ & abcde \\
\hline B. campestris (chinensis group) & Pak-choi & Yukishiro & $0^{\text {a) }}$ & 0000 & 00000 & 00000 & 00010 & 01000 & 00000 \\
\hline B. campestris (japonica group) & mizuna & Shirokukisenkin & 0 & 0020 & 00000 & 00000 & 00000 & 00000 & 00000 \\
\hline B. campestris (narinosa group) & rape & Shinbansei & 0 & 0000 & 00000 & 00000 & 00000 & 02000 & 00000 \\
\hline B. campestris (pekinensis group) & Chinese cabbage & Kashin & 0 & 0000 & 00000 & 00000 & 00000 & 00000 & 02200 \\
\hline B. campestris (pekinensis group) & Chinese cabbage & Nozaki-No. 2 & 0 & 0000 & 00000 & 00000 & 00000 & 00000 & 00000 \\
\hline B. campestris (rapifera group) & turnip & Hinona & 0 & 0000 & 00000 & 00000 & 00000 & 00000 & 00000 \\
\hline B. campestris (rapifera group) & turnip & Komatsuna & 0 & 0000 & 00000 & 00000 & 00000 & 00000 & 00200 \\
\hline B. campestris (rapifera group) & turnip & Wasekanamachi & 0 & 0101 & 22001 & 20000 & 13000 & 01100 & 00200 \\
\hline B. juncea (cernua group) & leaf mustard & Ha-karashina & 0 & 0000 & 00202 & 00000 & 00000 & 10000 & 00000 \\
\hline (botrytis group) & cauliflower & Nozakiwase & 4 & 4444 & 44433 & 42442 & 33220 & 44343 & 43433 \\
\hline B. oleracea (botrytis group) & cauliflower & Snowball & 4 & 4444 & 44444 & 44434 & 44344 & 44444 & 44444 \\
\hline B. oleracea (botrytis group) & cauliflower & Snow Crown & 4 & 4444 & 33323 & 40343 & 20323 & 23332 & 34433 \\
\hline (capitata group) & cabbage & Shikidori & 4 & 4444 & 44444 & 44444 & 44442 & 44444 & 44444 \\
\hline B. oleracea (italica group) & broccoli & Banrei & 4 & 4444 & 44444 & 44334 & 34343 & 44444 & 44444 \\
\hline B. napus (napobrassica group) & rutabaga & Green Top & 3 & 0003 & 33123 & 32222 & 20322 & 33433 & 22312 \\
\hline (daikon group) & Japanese radish & Miyashige & 0 & 0000 & 00000 & 00000 & 00000 & 00000 & 00000 \\
\hline (daikon group) & Japanese radish & Nerima & 0 & 0000 & 00000 & 00000 & 00000 & 00000 & 00000 \\
\hline
\end{tabular}

a) Disease index: 0, no sporulation or limited necrosis on inoculated cotyledons; 1 , sparse sporulation or large necrosis on inoculated cotyledons; 2 , sporulation on less than $19 \%$ of inoculated cotyledons; 3 , sporulation on $20 \%$ to $49 \%$ of inoculated cotyledons; 4 , sporulation on more than $50 \%$ of inoculated cotyledons. 
Table 3. Host reactions to single spore isolates of Peronospora parasitica on differential cultivars of Brassica oleracea

\begin{tabular}{|c|c|c|c|c|c|c|c|}
\hline \multirow{2}{*}{\multicolumn{2}{|c|}{ B. oleracea plants inoculated }} & \multicolumn{6}{|c|}{ Fungal isolates } \\
\hline & & \multicolumn{3}{|c|}{ Cabbage } & \multicolumn{3}{|c|}{ Broccoli } \\
\hline \multirow{2}{*}{ Crop } & \multirow{2}{*}{ Cultivar } & \multicolumn{2}{|c|}{$\mathrm{CPP} 5$} & \multirow{2}{*}{$\begin{array}{c}\text { CPP6 } \\
\mathrm{ab}\end{array}$} & \multirow{2}{*}{$\begin{array}{c}\text { BPP1 } \\
\text { ad }\end{array}$} & \multirow{2}{*}{$\frac{\mathrm{BPP} 2}{\mathrm{ac}}$} & \multirow{2}{*}{$\begin{array}{c}\mathrm{BPP} 3 \\
\mathrm{bd}\end{array}$} \\
\hline & & $\mathrm{d}$ & $\mathrm{e}$ & & & & \\
\hline Cauliflower & Akizuki & $4^{\text {a) }}$ & 4 & 44 & 44 & 44 & 44 \\
\hline Cauliflower & Bridal & 4 & 4 & 44 & 44 & 44 & 44 \\
\hline Cauliflower & Early Snowball A & 3 & 3 & 44 & 34 & 44 & 33 \\
\hline Cauliflower & Nozakiwase & 4 & 4 & 44 & 33 & 43 & 33 \\
\hline Cauliflower & Snowball & 4 & 4 & 44 & 44 & 44 & 44 \\
\hline Cauliflower & Snow Crown & 4 & 4 & 33 & 23 & 33 & 43 \\
\hline Cabbage & Delight Ball & 4 & 4 & 44 & $44^{-}$ & 44 & 44 \\
\hline Cabbage & Golden Best & 0 & 0 & 00 & 00 & 00 & 01 \\
\hline Cabbage & Kuroba-Succession & 4 & 4 & 44 & 44 & 44 & 44 \\
\hline Cabbage & Savoy King & 4 & 4 & 44 & 33 & 44 & 44 \\
\hline Cabbage & Shikidori & 4 & 4 & 44 & 44 & 44 & 44 \\
\hline Cabbage & YR-Sawamidori & 0 & 0 & 00 & 00 & 00 & 10 \\
\hline Broccoli & Banrei & 4 & 4 & 44 & 34 & 44 & 44 \\
\hline Broccoli & De Cico & 4 & 4 & 44 & 33 & 44 & 44 \\
\hline Broccoli & Ryokuyo & 4 & 4 & 44 & 33 & 34 & 44 \\
\hline Broccoli & Shinkai & 4 & 4 & 44 & 44 & 44 & 44 \\
\hline Broccoli & Tenrai & 4 & 4 & 44 & 44 & 44 & 44 \\
\hline Broccoli & Three Seven & 4 & 4 & 44 & 44 & 44 & 44 \\
\hline
\end{tabular}

a) Disease index: 0 , no sporulation or limited necrosis on inoculated cotyledons; 1 , sparse sporulation or large necrosis on inoculated cotyledons; 2, sporulation on less than 19\% of inoculated cotyledons; 3 , sporulation on $20 \%$ to $49 \%$ of inoculated cotyledons; 4 , sporulation on more than $50 \%$ of inoculated cotyledons.

\section{RESULTS}

\section{Host range}

The results of the host range tests, using the thirty single spore isolates of the downy mildew fungus and the cotyledons of five species of Cruciferae plants, are compiled in Table 2. Brassica oleracea was susceptible. The major disease indexes of cv. Banrei of broccoli, cv. Shikidori of cabbage and cv. Snowball of cauliflower were 4 , indicating that these cultivars are highly susceptible. These results clearly shows that $B$. oleracea is a host species of the fungus. B. napus (cv. Green Top of rutabaga) was moderately susceptible. The disease indexes were mostly 2 and 3 . This result suggests that $B$. napus is a possible host species of the fungus. $B$. campestris was resistant. Among the eight cultivars of five crops, the highest disease indexes was 2 in a few cases, most of the disease indexes were 0 . These results indicate that $B$. campestris is a non-host species. $B$. juncea (cv. Ha-karashina of leaf mustard, most disease indexes, 0 ) and Raphanus sativus (cv. Miyashige and cv. Nerima of Japanese radish, all disease indexes, 0) were also resistant, and considered to be non-host species. As a whole, it was considered that all the test isolates belong to one strain which is host-specific to $B$. oleracea and possibly to B. napus.

\section{Cultivar resistance}

Further inoculation tests were carried out to find resistant cultivars using ten isolates of the downy mildew fungus and each six cultivar of cauliflower, cabbage and broccoli. The results are compiled in Table 3. Two cultivars of cabbage, cv. Golden Best and cv. YR-Sawamidori, were resistant (most of disease indexes, 0 ). All the other cultivars were susceptible (most of disease indexes, 4). Variation of pathogenicity was not found among the single spore isolates.

\section{DISCUSSION}

To test the pathogenicity of some downy mildew fungus of Cruciferae plants, it is common to use the method of spraying inoculation to seedlings. In a preliminary inoculation tests of downy mildew fungus, we obtained the results (data not shown) that the disease reaction between cotyledons and leaves corresponded each other very well, suggesting that cotyledons are also a useful material for the host range tests. Therefore, as some researchers used cotyledons for inoculation of downy mildew fungus ${ }^{2,6,7,12)}$, too, we used cotyledons in the present experiments. Moreover, we also found that conidial suspensions with more than $10^{4}$ conidia $/ \mathrm{ml}$ were sufficient for the sprouting of the downy mildew fungus on most of the broccoli cotyledons (data not shown). Host range of downy mildew of Brassica oleracea was examined based on these informations.

Evidence based on host range studies on downy mildew $^{1-7,11,12)}$ and other biotrophic fungi indicates that host specificity occurs at different levels. Many experiments have been carried out at the genus, species and cultivar levels in cruciferous plants. In Japan, physiological specialization of the downy mildew fungus was 
observed only in $1934^{5)}$. Recently, we have examined the pathogenicity of downy mildew of $B$. oleracea to some Cruciferae crops $^{11)}$. The present results shows that the downy mildew fungus of broccoli and cabbage distributing in Japan belongs to one strain and host-species is specific to $B$. oleracea. $B$. napus may be a host species, but it is necessary to investigate particularly to confirm the possibility. These results were in agreement with previous reports indicating that downy mildew derived from $B$. oleracea generally displays a high host-species specificity $^{1,3,11,13)}$. Hiura and Kanegae ${ }^{5)}$ reported formerly that the downy mildew isolates derived from Japanese radish (Raphanus sativus) and some Brassica plants were not pathogenic to cabbage (B. oleracea). Therefore, some strains of downy mildew fungus of Cruciferae plants are considered to be distributing in Japan, and it is a future problem to draw full figures on the strains.

In the inoculation tests of different cultivars of $B$. oleracea, two cultivars of cv. Golden Best and cv. YRSawamidori, were found to be resistant, while other cultivars found to be a high to moderate susceptibility. It was suggested that these two cultivars may be useful materials for breeding resistant varieties of $B$. oleracea crops. Although the tested isolates were not infective to the cultivars, physiological races which is infective to the resistant cultivars may occur. In the United States of America, downy mildew fungus pathogenic to resistant cultivars have been detected and races have been differentiated ${ }^{8,13)}$. The survey of such races is another future problem.

We thank Drs. N. Tezuka and S. Horiuchi, National Research Institute of Vegetables, Ornamental Plants and Tea, Dr. F. Terami, Hokkaido National Agricultural Experiment Station, Mr. Y. Hagiwara, Japan Tobacco Inc. and Mr. H. Terauchi, Faculty of Agriculture, Iwate University, for their useful suggestions. We thank Dr. T. Ishijima, former National Research Institute of Vegetables, Ornamental Plants and Tea, for his critical reading of the manuscript. We are also grateful to Mr. A. Tomikawa, Mie Agricultural Research Center, Dr. I. Sako, Tottori Horticultural Experiment Station and Dr. M. Kusunoki, Kagawa Plant Protection Office, for their assistance in collecting fungal materials.

\section{Literature cited}

1. Chang, I.H., Shih, N.L. and Chiu, W.F. (1964). A preliminary study on the physiological differentiation of the downy mildews (Peronospora parasitica (Pers.) Fr.) of Chinese cabbage and other cruciferous vegetables in the vicinity of Peking and Tientsin. Acta Phytopathol. Sin. $7: 33-44$.

2. Dickinson, C.H. and Greenhalgh, J.R. (1977). Host range and taxonomy of Peronospora on crucifers. Trans. Br. Mycol. Soc. 69(1) : 111-116.

3. Dzhanuzakov, A. (1962). Specialization and variability of certain Peronospora fungi. Bot. Zh. USSR 47 : 862-867.

4. Gäumann, E. (1926). Über die Spezialisierung des fals- chen Mehltaus (Peronospora brassicae Gm.) auf dem Kohl und seinen Verwandten. Landw. Jbr. der Schweiz. $40: 463-468$

5. Hiura, M. and Kanegae, H. (1934). Studies on the downy mildews of cruciferous vegetables in Japan 1. Trans. Sapporo Nat. Hist. Soc. 13 : 125-133.

6. Kluczewski, S.M. and Lucas, J.A. (1983). Host infection and oospore formation by Peronospora parasitica in agricultural and horticultural Brassica species. Trans. Br. Mycol. Soc. 81(3) : 591-596.

7. McMeekin, D. (1969). Other hosts for Peronospora parasitica from cabbage and radish. Phytopathology 59 : 693696.

8. Natti, J.J., Dickson, M.H. and Atkin, J.D. (1967). Resistance of Brassica oleracea varieties to downy mildew. Phytopathology 57 : 144-147.

9. Ohguchi, T., Yoshida, K., Ismail, M.Y. and Asada, Y. (1989). A laboratory method for propagation of downy mildew fungus (Peronospora parasitica) using the cotyledon or true leaf of Japanese radish seedlings. Ann. Phytopathol. Soc. Jpn. 55 : 561-566.

10. Satou, M. and Fukumoto, F. (1993). Preservation of conidia of broccoli downy mildew fungus with cryogenic protectants by freezing at $-80^{\circ} \mathrm{C}$. Ann. Phytopathol. Soc. Jpn. 59 : 492-499.

11. Satou, M., Hagiwara, Y., Ishii, M. and Fukumoto, F. (1991). Downy mildew of broccoli caused by Peronospora brassicae. Proc. Kansai P1. Prot. Soc. 33 : 67-68 (in Japanese).

12. Sherriff, C. and Lucas, J.A. (1990). The host range of isolates of downy mildew, Peronospora parasitica, from Brassica crop species. Plant Pathol. 39 : 77-91.

13. Thomas, C.E. and Jourdain, E.L. (1990). Evaluation of broccoli and cauliflower germplasm for resistance to race 2 of Peronospora parasitica. Hortscience 25(11): 1429-1431.

\section{和 文 摘 要}

佐藤 衛・福本文良：キャベツおよびブロッコリー(Brassica oleracea)から分離したべと病菌(Peronospora parasitica)の宿主 範囲

香川県の 3 点のキャベツ, 三重県の 2 点および鳥取県の 1 点 のブロッコリーから Peronospora parasitica のサンプルを集め, 各サンプルから 5 菌株, 合計 30 の単胞子分離株を調製し, これ らの宿主範囲を調査した。供試植物として, Brassica oleracea (カリフラワー, キャベツおよびブロッコリー 18 品種)の他, $B$. campestris(タイサイ, ミズナ, アブラナ, ハクサイおよびカブ 8 品種), B. juncea (カラシナ 1 品種), B. napus (ルタバガ 1 品種) およびRaphanus sativus（ダイコン 2 品種）を用いた。接 種試験の結果, 分離源と同種の植物である B. oleracea の 3 作物 の 16 品種は高い感受性を示し, 本種は宿主植物と考えられた。 また，B. napus は中程度の感受性を示したことから宿主となる 可能性が示唆されたが, B. campestris, B. juncea, R. sativus は抵抗性を示したことから非宿主と考えられた。供試したべと 病菌はすべて同じ系統に属し, B. oleracea (B. napus も含む可 能性がある) を宿主とする系統と考えられた。B. oleracea の中 でキャベツの 2 品種, ゴールデンベストおよび YR-さわみどり は抵抗性を示した。供試した単胞子分離菌株で病原性に違いは 見られなかった。 